\title{
Management of newly established field margins on nutrient-rich soil to reduce weed spread and seed rain into adjacent crops
}

\author{
B DE CAUWER*, D REHEUL*, I NIJS $\dagger \&$ A MILBAU† \\ *Department of Plant Production, Faculty of Bioscience Engineering, Ghent University, Ghent, Belgium, and $\dagger$ Research Group of Plant and \\ Vegetation Ecology, Department of Biology, University of Antwerp, Wilrijk, Belgium
}

Received 20 October 2006

Revised version accepted 22 September 2007

\section{Summary}

We studied the effect of different ways to establish and to maintain unfertilised field margins on the development of potential weeds and seed dispersal into adjacent crops. Plant communities in field margins either developed spontaneously or were sown with different seed mixtures of grasses and forbs. Margins were mown twice a year and the cuttings were either removed or left in situ. Three years after establishment, the importance of the unsown rhizomatous species Elytrigia repens and Urtica dioica was significantly higher in the unsown community or when cuttings were not removed after mowing. Seed dispersal from the margin into adjacent crops was important in the unsown community during the first year after establishment. Between $82 \%$ and $99 \%$ of the seeds were disseminated within $4 \mathrm{~m}$ from the margin strip. Overall risk of contaminating the adjacent crop with weeds originating from the field margin strip was concentrated within a few metres of the crop edge. In order to minimise the dissemination of weed species and invasion by noxious vegetatively propagated weeds on nutrient-rich land, it is recommended that field margins are established by sowing and cuttings removed after each cut.

Keywords: anemochorous species, rhizomatous species, cutting, margin strips, buffer, dispersal, wind.

De Caumer B, Reheul D, Niss I \& Milbau A (2008). Management of newly established field margins on nutrientrich soil to reduce weed spread and seed rain into adjacent crops. Weed Research 48, 102-112.

\section{Introduction}

In many European countries, support mechanisms exist to encourage farmers to integrate nature and agriculture, e.g. by the establishment of margin strips. Farmers are reluctant to establish margin strips because they fear increased weed pressure in the cropped area adjacent to the strip (van der Meulen et al., 1996). The weed pressure in the cropped area might be affected by margin species adapted to wind or vegetative dispersal. Species with vigorous underground creeping root or rhizome systems such as Cirsium arvense (L.) Scop., Elytrigia repens (L.) Desv. ex Nevski and Convolvulus arvensis L. (Montegut, 1983) might invade into the cropped area, as reported by Marshall (1989) and Kleijn (1996). Seed dispersal from the margin strip into the cropped area might increase weed problems. Most species with no specialised dispersal structures (barachorous) are dispersed close to the parent plant (Howard et al., 1991). Seeds of anemochorous species (wind dispersed) are able to disperse over long distances but most seeds disperse over shorter distances than is often supposed (Feldman \& Lewis, 1990). Three studies of seed dissemination reported only small numbers of seeds moving more than $3 \mathrm{~m}$ (Rew et al., 1996), $7 \mathrm{~m}$ (Hume \& Archibold, 1986) or $12.5 \mathrm{~m}$ (Jones \& Naylor, 1992) into the cropped area. Most seeds of Anisantha sterilis L. (99\%) and of Anthriscus sylvestris (L.) Hoffm. (87\%) were disseminated within $1 \mathrm{~m}$ of the source in the field margin (Rew et al., 1996). According to Marshall (1989), field margin weeds have been found at greater density only

Correspondence: D Reheul, Faculty of Bioscience Engineering, Coupure Links 653, B-9000 Ghent, Belgium. Tel: (+32) 92646096 ; Fax: (+32) 9264 62 24; E-mail: dirk.reheul@ugent.be 
within the first 2-4 $\mathrm{m}$ of the field and few of these apparent invaders are also important weeds in the cropped area.

We hypothesised that the way a field margin is established and maintained affects the development of weed species in a field margin and their dissemination into adjacent crops. To test this, we compared natural regeneration with margins sown with several seed mixtures of grasses and forbs. Field margins were cut twice a year and cuttings either left, removed for both cuts or only removed for the first cut, thus creating situations encountered in other studies (e.g. Marshall \& Nowakowski, 1992), current practice or legal prescriptions. Both the development of potential weeds within the field margin and the dissemination of weeds into the adjacent crops were monitored.

\section{Materials and methods}

\section{Experimental details}

In June 2001, field margins were established on arable land in a split-plot design, with four plant communities (main factor), three herbage removal treatments (split factor) and three replicates (blocks). Different plant communities and herbage removal treatments were chosen to study their influence on botanical diversity (results reported by De Cauwer et al., 2005). The experiment was established on two contrasting soil types in the province of West Flanders, Belgium: a welldrained sandy loam at Poperinge $\left(50^{\circ} 52^{\prime} \mathrm{N}, 2^{\circ} 45^{\prime} \mathrm{E}, \mathrm{pH}-\right.$ $\mathrm{KCl} 6.8,1.5 \% \mathrm{C})$ and a sandy soil at Beernem $\left(51^{\circ} 09^{\prime} \mathrm{N}\right.$, $\left.3^{\circ} 20^{\prime} \mathrm{E}, \mathrm{pH}-\mathrm{KCl} 5.7,3.3 \% \mathrm{C}\right)$. Analysis of topsoil $(0-30 \mathrm{~cm})$ at Poperinge showed that extractable $\mathrm{P}$ and $\mathrm{K}$ were $27 \mathrm{mg}$ and $31 \mathrm{mg}$ per $100 \mathrm{~g}$ soil, respectively, and total mineral $\mathrm{N}$ was $43 \mathrm{~kg} \mathrm{ha}^{-1}$. Topsoil at Beernem had extractable $\mathrm{P}$ and $\mathrm{K}$ of $75 \mathrm{mg}$ and $31 \mathrm{mg}$ per $100 \mathrm{~g}$ soil, respectively, and total mineral $\mathrm{N}$ was $113 \mathrm{~kg} \mathrm{ha}^{-1}$. Hence, the margin strips were established on nutrientrich land and are therefore representative of most arable land in Flanders. The margin strips (each $360 \mathrm{~m} \times 10 \mathrm{~m}$ ) were established in a sward of 8-month-old Italian ryegrass (Lolium multiflorum L.). The sward was ploughed down in May 2001. Strips were divided into three blocks each comprising four main plots (plant communities) of $30 \mathrm{~m} \times 10 \mathrm{~m}$ arranged side by side at the southern side of an east-west oriented watercourse at Poperinge and an east-west oriented tree row at Beernem. Each main plot was subdivided in three subplots of $10 \mathrm{~m} \times 10 \mathrm{~m}$ (herbage removal strategies).

Four different plant communities were studied: an unsown spontaneously evolving plant community (CONTROL) and three sown communities (MIXT1, 2 and 3). MIXT1 was established with a seed mixture composed of 63 native plant species of local origin. The seed mixture was sown at $42.2 \mathrm{~kg} \mathrm{ha}^{-1}$ and included 45 non-leguminous dicotyledons, 6 legumes and 12 grasses in a proportion by seed weight of $16 \%, 22 \%$ and $62 \%$ respectively. MIXT2 was established with a commercially available seed mixture containing 77 species completely unrelated to the region. The seed mixture was sown at $40.7 \mathrm{~kg} \mathrm{ha}^{-1}$ and included 59 non-leguminous dicotyledons, 6 legumes and 12 grasses in proportion by seed weight of $12 \%, 23 \%$ and $65 \%$ respectively. Initially, the species compositions of MIXT3 and MIXT2 were identical, but once a year seed-rich herbage from neighbouring roadsides was added to MIXT3 to increase its species diversity. These roadsides were cut by the end of September. The fresh unchopped herbage was immediately transported and spread uniformly over the MIXT3 plots at a rate of approximately $0.5 \mathrm{~kg} \mathrm{~m}^{-2}$ of fresh herbage. Principal seed bearing species were Daucus carota L., Centaurea jacea L., Tanacetum vulgare L., Plantago lanceolata L., Torilis japonica (Houtt.) DC. and Pulicaria dysenterica (L.) Bernh.. Plant species in MIXT1 and MIXT2 were selected from a wide range of vegetation types: annual and perennial forbs from dry to moist grassland and perennial forbs thriving on nutrient-rich soils.

In 2001, the plots were cut once on 15 September and the cuttings were removed. In each of the following three years (2002-2004) they were cut twice, with the cut material either left or removed from the first only or both cuts, which resulted in three different herbage removal treatments. Plots were cut without disturbing the soil using an Agria mower with the cutter bar set at a height of $5 \mathrm{~cm}$. Mowing time followed the legal prescriptions of the agri-environment schemes managed by the Flemish Land Agency; to allow most species to set seed and to enhance the establishment of young seedlings, the first mowing date was postponed till 15 June (first cut). The vegetation was mown a second time in mid-September. Care was taken to avoid seed dispersal when removing the cut material.

No fertilisers or other agrochemicals were applied to the experimental plots. Crops adjacent to the field margins were conventionally managed at Poperinge and organically managed at Beernem. At both sites, arable land was maintained under conventional tillage. Crops immediately adjacent to the field margins at Poperinge were sugar beet (Beta vulgaris L. var. altissima) in 2001, winter wheat (Triticum aestivum L.) in 2002, silage maize (Zea mays L.) in 2003 and sugar beet in 2004. At Beernem, adjacent main crops were potato (Solanum tuberosum L.) in 2001, leek (Allium porrum L.) in 2002, carrot (D. carota) in 2003 and broccoli (Brassica oleracea L. var. italica) in 2004. All main crops were followed by rye (Secale cereale L.) as a winter cover 
crop. No fertiliser or pesticide drifted into the experiments as adjacent crops were always sprayed when the wind blew away from the margin strips. At Beernem, all main crops were shallow inter-row cultivated.

\section{Botanical composition}

Botanical analysis of margin strips was performed during succession to determine species presence with a particular emphasis on anemochorous and spreading species (here defined as invasive species propagating vegetatively). During the experimental period 2001-2004, the botanical composition of the vegetation was recorded twice per year on 15 July and 15 October, 30 days after every mowing date according to the combined frequency-rank method of De Vries for grassland monitoring (De Vries \& De Boer, 1959). For each species, species importance (expressed in \%) was derived from their presence in 16 quadrats $(13 \mathrm{~cm} \times 13 \mathrm{~cm})$ randomly placed within the central $4 \mathrm{~m} \times 4 \mathrm{~m}$ area of each subplot. All unsown specialised anemochorous species (assigned according to Bouman et al., 2000) and spreading species (assigned according to Montegut, 1983) in the plots were classified into the following species groups: annual unsown anemochorous species, perennial unsown anemochorous species and perennial unsown rhizomatous species. The $I \%$ of these groups was calculated by adding the $I \%$ of each species within a particular group. The species included in each group are listed in Table 1 with details of presence over the monitoring period 2001-2004 for each site. Species nomenclature and habitats followed Van Der Meijden (2005).

Specialised anemochorous species within sown mixtures were Leontodon autumnalis L., Leucanthemum vulgare Lam., Pastinaca sativa L., Rumex acetosa L., and Tragopogon pratensis L. Ingrowing sown species were Achillea millefolium L. and T. vulgare. However, these sown species, mainly typical grassland species, were not considered further as they were not considered as potential arable weeds for adjacent crops (Montegut, 1983).

The percentage bare ground (i.e. exposed mineral soil and litter) was estimated to investigate if the presence of anemochorous and ingrowing weeds was correlated with the percentage bare ground of the subplots. The percentage bare ground was estimated in eight randomly placed $80 \mathrm{~cm} \times 80 \mathrm{~cm}$ quadrats within the central $4 \mathrm{~m} \times 4 \mathrm{~m}$ area of each $10 \mathrm{~m} \times 10 \mathrm{~m}$ subplot.

\section{Seed rain}

Seed dispersal into the adjacent crop was monitored periodically around critical seed dispersal periods between 10 May and 10 June (hereafter May-June) and between 14 August and 9 September (hereafter August-September). Only anemochorous species were dispersing during this monitoring period. Monitoring occurred only when specialised anemochorous species in the margin strip were bearing maturing seeds. As a consequence, the monitoring during August-September was conducted in 2003 and 2004 at Poperinge and in 2002, 2003 and 2004 at Beernem. May-June monitoring was conducted at both sites in 2004 only. Seed rain was sampled on the southern side of the east-west oriented margin strips at both sites. Prevailing wind direction during all monitoring periods was north-northeast, therefore wind-borne seeds would potentially have been blown into the adjacent crop area. All wind-borne seeds captured in the adjacent crop were attributed to the field margins, as visual assessments revealed no seed dispersal originating from the surrounding perennial grassy verges or fields (Beernem: grazed grasslands revealing no anemochorous species; Poperinge: silage maize, during all monitoring years) or in the cropped area because the arable crops within this area were kept free of weeds by mechanical weeding (Beernem) or by herbicides (Poperinge). The seedrain next to each main plot was monitored by capturing seeds on blue biosignal traps (BUGSCAN-BIOBEST; BIOBEST, Westerlo, Belgium) sized $20 \mathrm{~cm} \times 40 \mathrm{~cm}$ with a sticky surface of $0.08 \mathrm{~m}^{2}$ facing northward. The traps were placed vertically $50 \mathrm{~cm}$ above ground level. In 2002, the traps were placed along 12 transects perpendicular to the east-west oriented main plots. The traps were placed at six positions along the transects: at $0,2,4,8,16$ and $32 \mathrm{~m}$ from the field margin edge. The seed traps were replaced weekly and captured wind-borne seeds were identified and counted. Only filled seeds were counted and for each species were expressed as seeds per $\mathrm{m}^{2}$ of sticky surface. In 2003 and 2004, the seedrain was monitored next to each subplot $0 \mathrm{~m}$ from the field margin strip, using three north facing sticky traps per east-west oriented subplot. Positions at greater distance from the field margin were not monitored, as overall seed dispersal was very low at both sites.

\section{Statistical analysis}

Changes in $I \%$ of individual plant species or species groups over the period 2001-2004 were analysed using linear regression analysis (statistical package sPss 10.0 for Windows; SPSS Inc., Chicago, IL, USA). For the $I \%$ of the anemochorous species linear regression was performed on the July and October data separately, due to the seasonal variation in species presence and importance of anemochorous species over time. For the rhizomatous species with less seasonal variation, the regression was based only on October data. S-plus 2000 


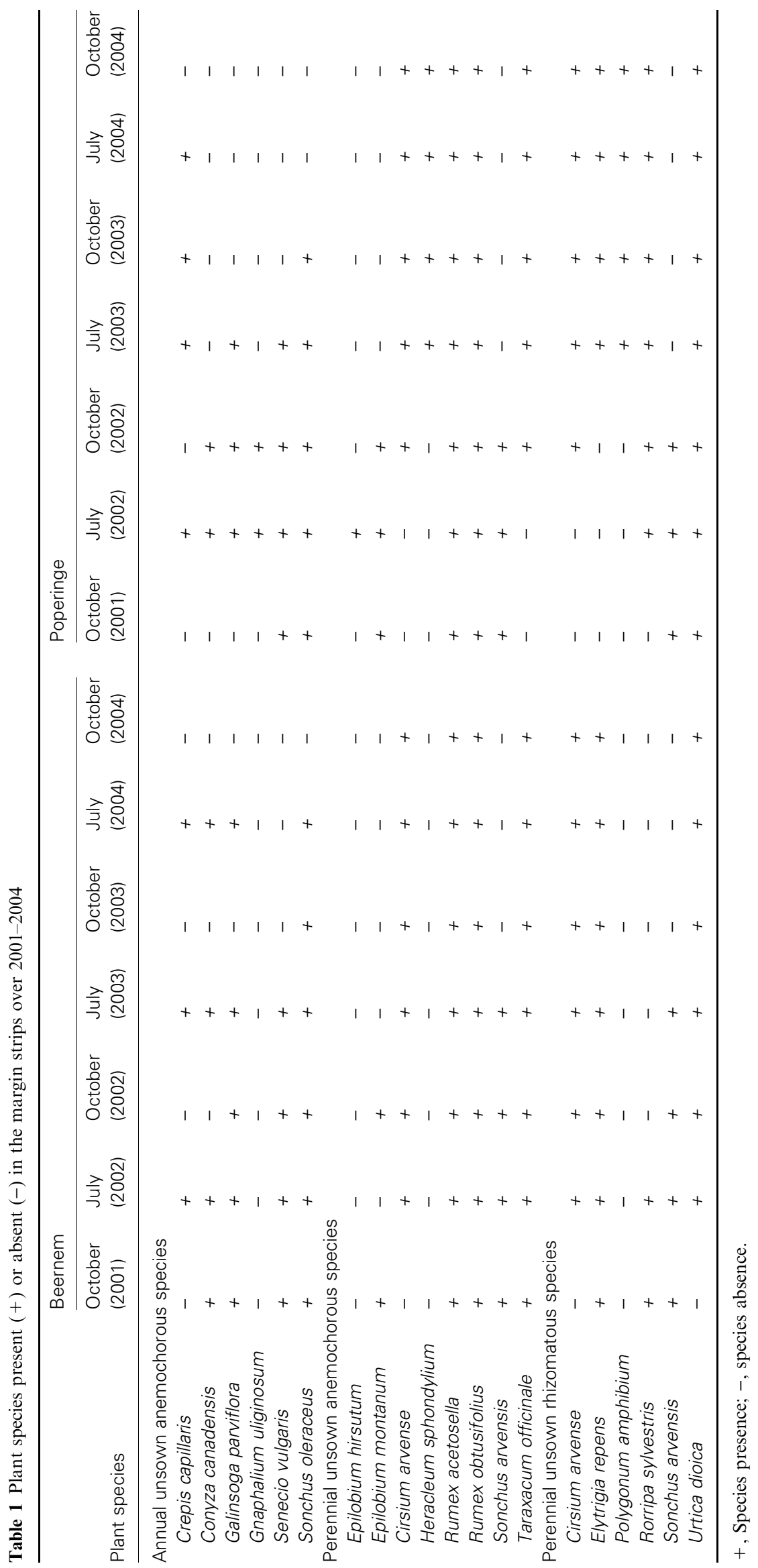


for Windows (Krause \& Olson, 2000) was used to carry out the statistical computations for analysis of variance (ANOVA) of a split-plot design according to Gomez \& Gomez (1984). The two sites were considered as replicates, in order to focus upon the effects of the true treatments: plant community and herbage removal strategy. Indeed, preliminary analysis of percentage bare ground, $I \%$ of species groups and seedrain over the period 2001-2004, using an ANOVA for a strip split-plot design (vertical factor $=$ site, horizontal factor $=$ plant community, subplot factor $=$ herbage removal treatment), almost always revealed no significant site effects nor significant interactions with the factor site. All data were tested for normal distribution. To meet the standards of the ANOVA, total number of captured seeds were transformed to $(x+0.5)^{1 / 2}$.

\section{Results}

\section{Vegetation analysis}

The percentage bare ground and significance of individual factors and interactions are presented in Table 2. In October 2001, the unsown plant community revealed a significantly higher percentage bare ground than the sown plant communities. Conversely, 3 years later, in October 2004, the actual percentage bare ground was significantly lower in the unsown community than in the sown plant communities. Over the period 2002-2004, the percentage bare ground in July and October was significantly higher when cuttings were left than when removed after both cuts. The percentage bare ground significantly decreased over time, both in the unsown community and when both cuttings were removed.

The $I \%$ of both annual and perennial unsown anemochorous species during the experimental period 2001-2004 are summarised in Table 3. From July 2002 to October 2003, the unsown community revealed a significantly higher $I \%$ of annual unsown anemochorous species than the sown communities except for July 2003. In 2004, values were low and not significantly different. Over time the $I \%$ of annual unsown anemochorous species significantly decreased irrespective of plant community or herbage removal treatment. Three years after establishment, the $I \%$ of annual unsown anemochorous species was not significantly affected by plant community or by herbage removal treatment. Correlation between the $I \%$ of annual unsown anemochorous species in July 2002, and percentage bare ground in October 2001 revealed a highly positive and significant correlation of $0.58(P=0.02)$.

From October 2001 to October 2004, the $I \%$ of perennial unsown anemochorous species was determined only by plant community with a significantly higher $I \%$ for the unsown community compared with the sown communities. In the unsown community, it significantly decreased over time (irrespective of the herbage removal treatment) but it significantly increased in MIXT1, while changes were not significantly different in MIXT2 and MIXT3. In July 2002, the most important

Table 2 Bare ground (\%) in sown/unsown margin strips 2001-2004

\begin{tabular}{|c|c|c|c|c|c|c|c|c|c|}
\hline \multirow[b]{2}{*}{$\begin{array}{l}\text { Plant } \\
\text { community }\end{array}$} & \multirow{2}{*}{$\begin{array}{l}\text { Herbage } \\
\text { removal } \\
\text { treatment }\end{array}$} & \multicolumn{7}{|l|}{ Time } & \multirow[b]{2}{*}{ Slope $^{\dagger}$} \\
\hline & & $\begin{array}{l}\text { October } \\
\text { (2001) }\end{array}$ & $\begin{array}{l}\text { July } \\
(2002)\end{array}$ & $\begin{array}{l}\text { October } \\
(2002)\end{array}$ & $\begin{array}{l}\text { July } \\
\text { (2003) }\end{array}$ & $\begin{array}{l}\text { October } \\
(2003)\end{array}$ & $\begin{array}{l}\text { July } \\
\text { (2004) }\end{array}$ & $\begin{array}{l}\text { October } \\
(2004)\end{array}$ & \\
\hline \multicolumn{2}{|l|}{ CONTROL } & 71.8 & 39.2 & 30.6 & 28.5 & 20.3 & 37.7 & 20.2 & $-16.52 * * *$ \\
\hline \multicolumn{2}{|l|}{ MIXT1 } & 29.2 & 27.6 & 31.1 & 28.6 & 29.6 & 34.0 & 30.1 & 0.12 \\
\hline \multicolumn{2}{|l|}{ MIXT2 } & 37.2 & 27.8 & 33.5 & 35.5 & 32.6 & 45.2 & 42.2 & 1.40 \\
\hline \multirow[t]{4}{*}{ MIXT3 } & & 35.7 & 31.3 & 63.1 & 33.8 & 42.6 & 43.0 & 38.5 & -1.21 \\
\hline & REMOVO & 44.6 & 50.5 & 48.8 & 45.6 & 41.1 & 54.9 & 41.1 & -1.81 \\
\hline & REMOV1 & 41.2 & 24.3 & 43.2 & 26.4 & 32.7 & 34.1 & 36.3 & $-2.52^{*}$ \\
\hline & REMOV2 & 44.7 & 19.7 & 26.8 & 22.7 & 20.0 & 30.9 & 20.8 & $-7.84^{* * *}$ \\
\hline \multicolumn{10}{|l|}{ ANOVA } \\
\hline \multicolumn{2}{|c|}{ Plant community } & $* *$ & NS & $* * *$ & NS & $* * *$ & NS & $* * *$ & \\
\hline \multicolumn{2}{|c|}{ SEM (d.f. = 15) } & 9.81 & 1.27 & 3.66 & & 3.19 & & 3.61 & \\
\hline \multicolumn{2}{|c|}{$\begin{array}{l}\text { Herbage removal } \\
\text { treatment }\end{array}$} & NS & $* * *$ & $* * *$ & $* * *$ & $* * *$ & $* * *$ & $* * *$ & \\
\hline \multicolumn{2}{|c|}{ SEM (d.f. $=40$ ) } & & 2.32 & 2.47 & 2.27 & 2.52 & 2.28 & 2.82 & \\
\hline \multicolumn{2}{|c|}{$\begin{array}{l}\text { Plant } \\
\text { community } \times \text { herbage } \\
\text { removal treatment }\end{array}$} & NS & NS & NS & NS & NS & NS & NS & \\
\hline
\end{tabular}

${ }^{*} P<0.05 ;{ }^{* *} P<0.01 ;{ }^{* * *} P<0.001$; NS, not significant; SEM, standard error of difference between means, residual degree of freedom in brackets.

${ }^{\dagger}$ Slope $\left(\%\right.$ year $\left.^{-1}\right)$ of linear regression equation of bare ground percentage on time (based on October surveys). 


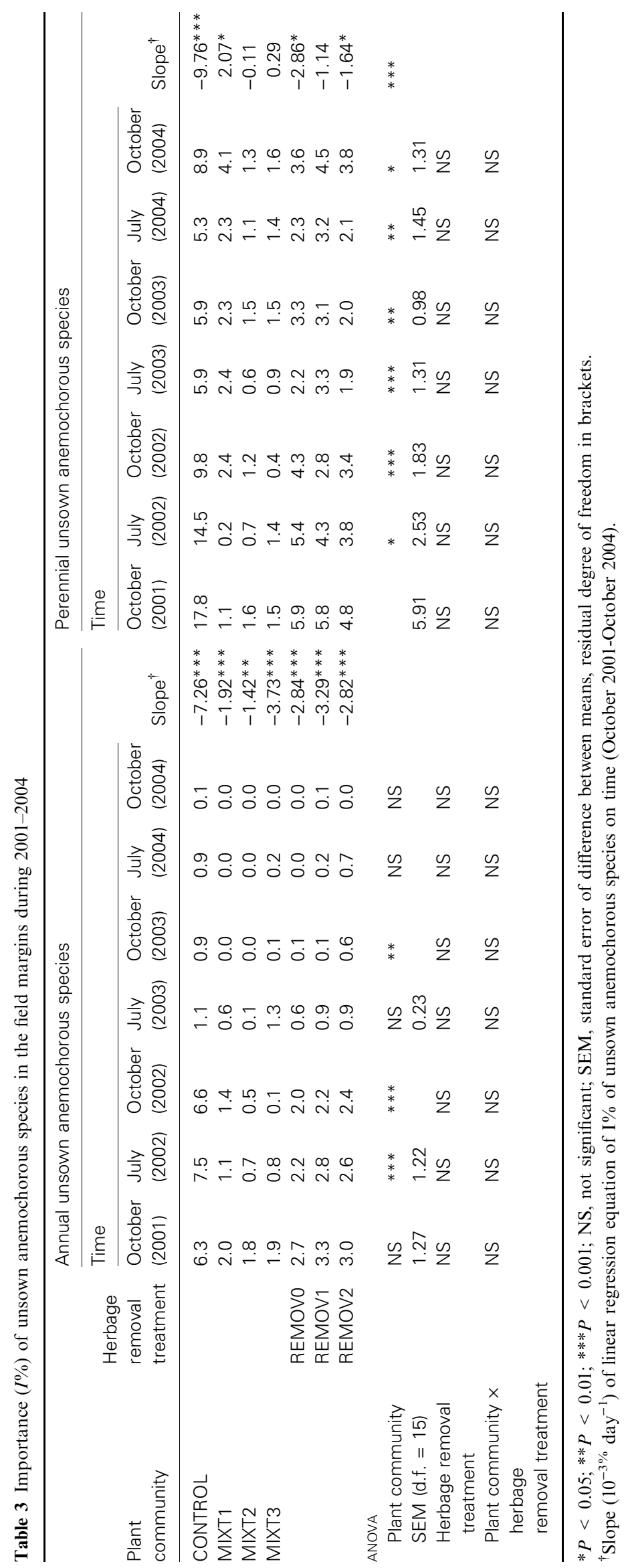


anemochorous weed species was Sonchus arvensis L. Its importance was determined by plant community $(P=0.001)$ with a significantly higher $I \%$ for the unsown community compared with the sown communities: $11.4 \%$ in CONTROL versus $0.2-0.5 \%$ in sown communities $(\mathrm{LSD}=5.2 \%)$. Other important species in July 2002 were Rumex obtusifolius L. and Taraxacum officinale with an overall mean $I \%$ of $0.5 \%$ and $0.4 \%$ respectively. No significant factors or interactions were found for either species. Three years after establishment in July 2004, S. arvensis had totally disappeared whilst the overall mean importance of $R$. obtusifolius and T. officinale had increased slightly to $0.9 \%$ and $0.6 \%$ respectively. No significant factors or interactions were found for $R$. obtusifolius, whilst $T$. officinale had a significantly greater importance in CONTROL than in sown communities $(1.3 \%$ in CONTROL versus $0.3-$ $0.5 \%$ in sown communities; LSD $=0.8 \%$ ).

A highly significant positive correlation of 0.67 $(P<0.006)$ was found between the $I \%$ of perennial unsown anemochorous species in July 2002, and the percentage bare ground in October 2001.

$I \%$ in October of the most pernicious rhizomatous species recorded in this study (C. arvense, E. repens and Urtica dioica L.) are summarised in Table 4. In October 2004 , the $I \%$ of these species was significantly determined by plant community (except for $C$. arvense) and herbage removal treatment. Compared to sown communities, the unsown community revealed a significantly higher $I \%$ of $E$. repens and $U$. dioica. The $I \%$ of $C$. arvense, E. repens and $U$. dioica was significantly higher in REMOV0. During 2001-2004, the $I \%$ of $U$. dioica, E. repens and C. arvense significantly increased in REMOV0 and in the unsown community (except for E. repens).

\section{Seed dispersal into adjacent crop}

One year after establishment, in August-September 2002, the total number of captured seeds in the adjacent crop at Beernem was significantly determined by plant community $(P<0.05)$. Seed rain into the adjacent crop was significantly higher next to the unsown community than next to sown communities (Table 5).

Seed dispersal adjacent to CONTROL and MIXT1 decreased exponentially with increasing distance into the crop (Table 6). Most seeds were captured within the first $4 \mathrm{~m}$ of the crop: between $81 \%$ and $97 \%$ of all captured seeds were disseminated within this distance (Table 6).

In the control plots seed dispersal distance (Fig. 1) was determined by plant species (seed density at maximum dispersal distance between brackets): seeds of Galinsoga parviflora (2.5 seeds $\mathrm{m}^{-2}$ ) were only disseminated within the first $4 \mathrm{~m}$ of the crop; Sonchus oleraceus $\left(3.75\right.$ seeds $\left.\mathrm{m}^{-2}\right)$ and $S$. arvensis $\left(2.5\right.$ seeds $\left.\mathrm{m}^{-2}\right)$ were detected up to $16 \mathrm{~m}$ within the crop. Conyza canadensis (L.) Cronquist (33.7 seeds $\mathrm{m}^{-2}$ ) showed the highest seed dispersal distance $(32 \mathrm{~m})$. It is very

Table 4 Importance $(I \%)$ of some pernicious unsown rhizomatous margin species during the period 2002-2004

\begin{tabular}{|c|c|c|c|c|c|c|c|c|c|c|c|c|c|}
\hline \multirow{4}{*}{$\begin{array}{l}\text { Plant } \\
\text { community }\end{array}$} & \multirow{4}{*}{$\begin{array}{l}\text { Herbage } \\
\text { removal } \\
\text { treatment }\end{array}$} & \multicolumn{4}{|c|}{ Cirsium arvense } & \multicolumn{4}{|c|}{ Elytrigia repens } & \multicolumn{4}{|c|}{ Urtica dioica } \\
\hline & & \multicolumn{3}{|l|}{$1 \%$} & \multirow[b]{3}{*}{ Slope $^{\dagger}$} & \multicolumn{3}{|l|}{$1 \%$} & \multirow[b]{3}{*}{ Slope $^{\dagger}$} & \multicolumn{3}{|l|}{$1 \%$} & \multirow[b]{3}{*}{ Slope $^{\dagger}$} \\
\hline & & \multicolumn{3}{|c|}{ October } & & \multicolumn{3}{|c|}{ October } & & \multicolumn{3}{|c|}{ October } & \\
\hline & & 2002 & 2003 & 2004 & & 2002 & 2003 & 2004 & & 2002 & 2003 & 2004 & \\
\hline \multicolumn{2}{|l|}{ CONTROL } & 0.3 & 1.0 & 2.9 & $1.31^{* *}$ & 5.5 & 9.3 & 8.2 & 1.35 & 0.2 & 0.7 & 3.1 & $1.88^{* *}$ \\
\hline \multicolumn{2}{|l|}{ MIXT1 } & 0.0 & 0.2 & 0.8 & $0.41 *$ & 1.8 & 4.1 & 2.2 & 0.18 & 0.2 & 0.8 & 2.4 & $1.54^{*}$ \\
\hline \multicolumn{2}{|l|}{ MIXT2 } & 0.0 & 0.0 & 0.0 & & 1.2 & 1.3 & 4.1 & 1.48 & 0.0 & 0.0 & 0.2 & $0.21 *$ \\
\hline \multirow[t]{4}{*}{ MIXT3 } & & 0.1 & 0.0 & 0.0 & -0.07 & 1.7 & 1.4 & 2.7 & 0.51 & 0.0 & 0.0 & 0.4 & $0.37^{*}$ \\
\hline & REMOVO & 0.0 & 0.1 & 1.2 & $0.59 *$ & 2.6 & 5.7 & 7.9 & $2.62^{*}$ & 0.1 & 0.7 & 3.0 & $1.45^{*}$ \\
\hline & REMOV1 & 0.0 & 0.2 & 1.1 & $0.56^{*}$ & 2.8 & 3.3 & 2.9 & 0.05 & 0.1 & 0.4 & 1.0 & $0.44^{*}$ \\
\hline & REMOV2 & 0.3 & 0.5 & 0.5 & 0.10 & 2.2 & 3.2 & 2.1 & -0.03 & 0.0 & 0.0 & 0.5 & $0.25 *$ \\
\hline \multicolumn{14}{|l|}{ ANOVA } \\
\hline \multicolumn{2}{|c|}{ Plant community } & NS & * & NS & & NS & $*$ & * & & NS & NS & * & \\
\hline \multicolumn{2}{|c|}{ SEM (d.f. = 15) } & & 0.42 & & & & 2.72 & 2.63 & & & & 1.03 & \\
\hline \multicolumn{2}{|c|}{$\begin{array}{l}\text { Herbage removal } \\
\text { treatment }\end{array}$} & * & NS & * & & NS & $*$ & $*$ & & NS & NS & * & \\
\hline \multicolumn{2}{|c|}{ SEM (d.f. $=40$ ) } & 0.14 & & 0.29 & & & 1.14 & 1.88 & & & & 1.04 & \\
\hline \multicolumn{2}{|c|}{$\begin{array}{l}\text { Plant } \\
\text { community } \times \text { herbage } \\
\text { removal treatment }\end{array}$} & NS & NS & NS & & NS & NS & NS & & NS & NS & NS & \\
\hline
\end{tabular}

$P<0.05 ;{ }^{* *} P<0.01 ;{ }^{* * *} P<0.001$; NS, not significant; SEM, standard error of difference between means, residual degree of freedom in brackets.

${ }^{\dagger}$ Slope $\left(\%\right.$. year $\left.^{-1}\right)$ of linear regression equation of $I \%$ on time (2002-2004, based on October surveys). 
Table 5 Total number of seeds (seeds $\mathrm{m}^{-2}$ sticky surface) captured in the adjacent crop up to a distance of $32 \mathrm{~m}$ from the edge of field margin strips established with unsown and sown plant communities (Beernem; 14 August to 9 September 2002)

\begin{tabular}{lccccc}
\hline & \multicolumn{2}{l}{ Plant species } & & & \\
\cline { 2 - 5 } Plant community & $\begin{array}{l}\text { Sonchus } \\
\text { oleraceus }\end{array}$ & $\begin{array}{l}\text { Sonchus } \\
\text { arvensis }\end{array}$ & $\begin{array}{l}\text { Conyza } \\
\text { canadensis }\end{array}$ & $\begin{array}{l}\text { Galinsoga } \\
\text { parviflora }\end{array}$ & Total seed dispersal \\
\hline CONTROL & $840 \pm 536.4$ & $1148 \pm 479.8$ & $1481 \pm 1481.8$ & $2 \pm 2.1$ & $3471 \pm 1787.4(55 \pm 15.6)^{\mathrm{a}}$ \\
MIXT1 & $33 \pm 18.2$ & $96 \pm 65.5$ & $0 \pm 0.0$ & $0 \pm 0.0$ & $129 \pm 72.6(10 \pm 3.6)^{\mathrm{b}}$ \\
MIXT2 & $25 \pm 19.1$ & $633 \pm 577.9$ & $0 \pm 0.0$ & $0 \pm 0.0$ & $658 \pm 596.5(19 \pm 12.1)^{\mathrm{b}}$ \\
MIXT3 & $42 \pm 41.7$ & $554 \pm 547.9$ & $0 \pm 0.0$ & $0 \pm 0.0$ & $596 \pm 589.6(15 \pm 13.5)^{\mathrm{b}}$ \\
\hline
\end{tabular}

In brackets: data transformed $(x+0.5)^{1 / 2}$; no significant differences between figures with the same letter $($ LSD, $P=0.05)$. Mean values \pm SE.

Table 6 Total number of seeds captured in the adjacent crop at six distances from the edge of field margin strips established with sown and unsown plant communities (Beernem; 14 August to 9 September 2002)

\begin{tabular}{|c|c|c|c|c|c|c|c|}
\hline \multirow[b]{2}{*}{ Plant community } & \multicolumn{6}{|c|}{ Distance from field margin strip $(\mathrm{m})$} & \multirow[b]{2}{*}{ Total } \\
\hline & 0 & 2 & 4 & 8 & 16 & 32 & \\
\hline CONTROL & $1531.3(35.7)^{\mathrm{a}}$ & $793.8(27.0)^{\mathrm{ab}}$ & $479.2(20.7)^{\mathrm{abc}}$ & $439.6(16.9)^{\mathrm{bc}}$ & $193.8(9.4)^{\mathrm{bc}}$ & $33.3(3.8)^{\mathrm{c}}$ & 3470.8 \\
\hline MIXT1 & $91.7(8.3)^{\mathrm{a}}$ & $29.2(4.7)^{\mathrm{ab}}$ & $4.2(1.7)^{\mathrm{b}}$ & $0.0(0.7)^{\mathrm{b}}$ & $4.2(1.7)^{\mathrm{b}}$ & $0.0(0.7)^{\mathrm{b}}$ & 129 \\
\hline MIXT2 & $45.8(6.4)^{\mathrm{a}}$ & $41.2(8.2)^{\mathrm{a}}$ & $441.7(13.5)^{\mathrm{a}}$ & $29.2(4.0)^{\mathrm{a}}$ & $0.0(0.7)^{\mathrm{a}}$ & $0.0(0.7)^{a}$ & 658.3 \\
\hline MIXT3 & $16.7(3.5)^{\mathrm{a}}$ & $320.8(10.8)^{a}$ & $241.7(9.5)^{a}$ & $16.7(2.8)^{\mathrm{a}}$ & $0.0(0.7)^{a}$ & $0.0(0.7)^{\mathrm{a}}$ & 595.8 \\
\hline
\end{tabular}

In brackets: data transformed $(x+0.5)^{1 / 2}$; no significant differences between figures with the same letter (LSD, $\left.P=0.05\right)$, comparison within same plant community only.

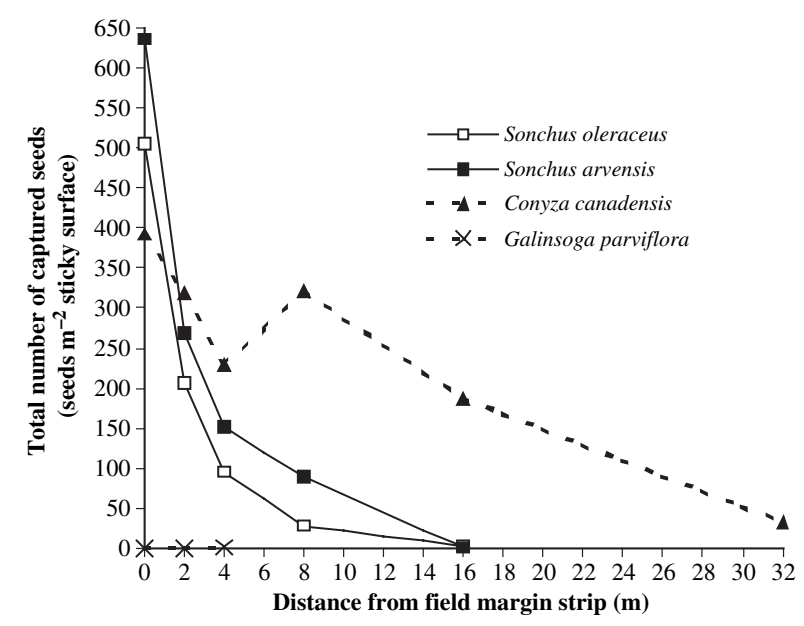

Fig. 1 Seed dispersal (seeds $\mathrm{m}^{-2}$ sticky surface) of four plant species into the adjacent crop at increasing distances from the unsown margin strip. Site: Beernem. Monitoring period: 14 August to 9 September 2002.

probable that the seeds of $C$. canadensis spread beyond this distance, but this was not monitored.

Two years after establishment, in August-September 2003 seed dispersal of unsown anemochorous species into the adjacent crop was similarly low for all plant communities (Table 7). Compared with the preceding year (see Table 6), seed dispersal at $0 \mathrm{~m}$ from the margin strip was low. Three years after establishment in MayJune 2004, only seeds of $T$. officinale were captured at $0 \mathrm{~m}$ from the margin strip. The number of captured seeds was significantly higher next to the unsown community than next to sown communities.

The number of captured wind-borne seeds of both annual, perennial and total unsown anemochorous species, in August-September 2002 was significantly positively correlated with their $I \%$ in July 2002 with correlation coefficients of $0.89 \quad(P<0.001), 0.53$ $(P=0.008), 0.94 \quad(P<0.001)$ respectively. Similar significantly positive correlations were found for individual disseminating species with correlation coefficients of $0.61 \quad(P=0.006), 0.86(P<0.001)$ and 0.91 $(P<0.001)$ for $S$. arvensis, S. oleraceus and C. canadensis respectively. No significant correlation coefficients were found in 2003. In 2004, there was a significant positive correlation between $I \%$ of $T$. officinale prior to seed monitoring (October 2003) and the number of captured seeds $(r=0.49, P=0.023)$.

\section{Discussion}

Some farmers are reluctant to establish margin strips because they fear weed invasion and seed dispersal into adjacent crops. Weed species with the potential to spread were sensitive to management practices, in particular plant community type and herbage removal treatment. Three perennial weed species which have the largest impact on yields of many crops in northern Europe (Naylor 2002) are E. repens, C. arvense and $S$. arvensis, which are found adjusting root and shoot 
Table 7 Captured wind-borne seeds (seeds $\mathrm{m}^{-2}$ sticky surface) next to plant communities at $0 \mathrm{~m}$ from the edge of field margin strips (Period 2003-2004, Beernem and Poperinge)

\begin{tabular}{|c|c|c|c|c|}
\hline & \multicolumn{3}{|l|}{ August-September 2003} & \multirow{2}{*}{$\frac{\text { May-June } 2004}{\text { Perennials }}$} \\
\hline & Annuals & Perennials & Total & \\
\hline \multicolumn{5}{|c|}{ Plant community } \\
\hline CONTROL & $6.1 \pm 8.43(1.7 \pm 1.12)^{a}$ & $8.3 \pm 14.31(1.7 \pm 1.45)^{a}$ & $14.4 \pm 20.31(2.4 \pm 1.82)^{a}$ & $46.1 \pm 31.32(5.4 \pm 2.49)^{a}$ \\
\hline MIXT1 & $0.0 \pm 0.00(0.7 \pm 0.00)^{\mathrm{b}}$ & $4.4 \pm 9.54(1.3 \pm 1.08)^{\mathrm{a}}$ & $4.4 \pm 9.54(1.3 \pm 1.08)^{a}$ & $4.4 \pm 4.53(1.6 \pm 0.90)^{b}$ \\
\hline MIXT2 & $0.0 \pm 0.00(0.7 \pm 0.00)^{\mathrm{b}}$ & $5.6 \pm 6.92(1.6 \pm 1.09)^{a}$ & $5.6 \pm 6.92(1.6 \pm 1.09)^{a}$ & $1.7 \pm 2.21(1.1 \pm 0.56)^{\mathrm{b}}$ \\
\hline MIXT3 & $5.0 \pm 7.48(1.5 \pm 1.08)^{\mathrm{ab}}$ & $18.9 \pm 28.69(2.6 \pm 2.11)^{a}$ & $23.9 \pm 29.51(3.1 \pm 2.28)^{a}$ & $2.2 \pm 3.16(1.2 \pm 0.67)^{b}$ \\
\hline \multicolumn{5}{|c|}{ Seed dispersing species } \\
\hline & Sonchus oleraceus & Sonchus arvensis & Sonchus oleraceus & Taraxacum officinale \\
\hline & Crepis capillaris & Heracleum sphondylium & Crepis capillaris & \\
\hline & & & Sonchus arvensis & \\
\hline & & & Heracleum sphondylium & \\
\hline
\end{tabular}

In brackets: data transformed $(x+0.5)^{1 / 2}$; no significant differences between figures with the same letter $(\mathrm{LSD}, P=0.05)$; comparison within groupings only. Mean values \pm SE.

growth into locally resource-rich zones (Campbell et al., 1991; Kleijn, 1996). Sonchus arvensis disappeared after 3 years in our plots, but E. repens, C. arvense and $U$. dioica significantly increased over time when both cuttings were not removed. Mowing with removal of cuttings enhanced the mineral depletion of the soil (Nevens \& Reheul, 2002), thus taking away optimal growing conditions for spreading species. Indeed, Marshall (1990) found that fertiliser use doubled the growth and spread of E. repens rhizomes. Mowing with removal of cuttings also reduced the percentage bare ground over time significantly, thus reducing gaps prone to colonising species.

Spreading species are better suppressed by sown margin strips than by unsown strips; their presence remaining low in sown communities. Similar results were reported by West et al. (1997) and Bokenstrand et al. (2004). The success of spreading species in the unsown community is probably better explained by the low competitiveness of the vegetation (reported by De Cauwer et al., 2006) than by the presence of invadable gaps. The initial presence of gaps 1 year after establishment was weakly correlated with the importance of spreading species 2 years later. However, the correlation between gaps and the importance of spreading species was strong in the more productive and competitive sown communities. Scarification of sown margin strips has been shown to allow some annual and rhizomatous species to increase (Westbury et al., 2008). Bare ground levels might predict the susceptibility of sown communities to invasion by spreading species.

Weed problems might increase as a result of seed rain from anemochorous margin species into the adjacent crop. The first year after establishment, four to eight times more wind-borne seeds were captured next to the unsown community than next to sown communities. Indeed, unsown field margin strips were hot spots for specialised anemochorous species, particularly the first year after establishment. Over time, bare ground levels decreased to levels lower than in sown communities and the significance of the correlation between gaps and importance of anemochorous species was lost. This indicates that for closed swards, the invasive success of anemochorous species is better explained by competitiveness of the vegetation than by the availability of gaps. Gaps in lowgrowing unsown communities might be invaded faster than gaps in sown communities. Indeed, in a dense sward it is more difficult for a seed to reach the soil. Even when it does reach the soil and germinates, the resulting plantlet might not survive due to the low light penetration. West $e t$ al. (1997) found that sowing a grass/clover mixture reduced weed pressure in the sown strip compared with options that left the sward more open.

However, the seed rain from the unsown margin strip into the adjacent crop significantly decreased over time reflecting both the significant decrease in importance of annual and perennial specialised anemochorous species and the decrease in invadable gaps over time. Three years after establishment, there was no wind-borne seed dispersal by annual species irrespective of plant community. Future anemochorous seed dispersal will greatly depend on the presence of perennial anemochorous species typically found in grasslands, such as T. officinale.

Seed dispersal by specialised anemochorous species was not significantly affected by the herbage removal strategy, despite the significantly higher percentage bare ground when cuttings were not removed. Low light penetration below the remaining litter probably inhibited seed germination of anemochorous species but enhanced colonisation of gaps by spreading species.

More than $80 \%$ of all dispersed seeds were disseminated within $4 \mathrm{~m}$ from the field margin strip irrespective of plant community. This is in accordance with studies 
of Hume \& Archibold (1986) and Jones \& Naylor (1992) who quote that a high proportion of the seed rain falls within 7 or $12.5 \mathrm{~m}$ of the margin respectively. However, seed dispersal distance differed between species, with a high dispersal distance (up to $32 \mathrm{~m}$ ) for $C$. canadensis and a short distance for G. parviflora.

Seed dissemination mainly occurred in August-September, when $S$. oleraceus (Beernem, Poperinge), S. arvensis (Beernem) and C. canadensis (Beernem) were the most important weed species present in the seed rain. The risk for crop yield effects was probably low, as crops adjacent to the field margins were either summer crops (leek, carrot in Beernem) ready to be harvested or were closed dense crops in the autumn (maize and sugar beet in Poperinge). However, seeds landing in the cropped area might create a problem in following crops depending on the seed longevity, dormancy and survival at different depths. Seeds of S. oleraceus and S. arvensis do not persist for a long time in cultivated soil; their viability lies between 1 and 5 years (Hutchinson et al., 1984). The shallow cultivations at Beernem prior to drilling and the repeated mechanical weeding may prevent seed survival or establishment of Sonchus spp. Furthermore, their germination is enhanced by light. As a consequence, their emergence may be inhibited by tall vegetation (Hutchinson et al., 1984), such as maize or in crops with a dense leaf canopy, such as sugar beet in Poperinge.

Seeds of the winter annual $C$. canadensis can remain viable in the seedbank for 10-12 years (Bàrberi \& Lo Cascio, 2000), but the species is very susceptible to tillage (Tremmel \& Peterson, 1983) and to a competitive cover crop (Leroux et al., 1996). Tillage may reduce the survival by over $90 \%$ (Leroux et al., 1996).

The establishment of field margins by sowing grass/forbs was the most beneficial option in terms of weed control, irrespective of whether cuttings were removed or not. From a nature conservation point of view, unsown margin strips might be preferred if the arable land, prior to the establishment of the margin, is relatively weed-free, as suggested by Kleijn (1997). According to De Cauwer et al. (2005), species richness and composition in sown and unsown margin strips converged over time. So, establishing field margins by sowing, irrespective of whether the field is weed infested or not, minimises potential weed risks without endangering nature conservation objectives. These results reflect those reported by Smith et al. (1999).

Although species composition differed between sites as reported by De Cauwer et al. (2005), this did not result in differences in the importance of the anemochorous and spreading species. Site effects would probably be more pronounced if the experiment had been established on sites widely differing in soil nutrient levels, producing swards with different levels of competition.

In conclusion, the potential risk of contaminating the adjacent crop with weeds originating from the field margin is highest at the crop edge due to the presence of rhizomatous weeds and the limited long-distance dispersal of seeds. The best way to control the development of noxious weeds within a newly established field margin is to establish the margin by sowing and to remove the cuttings after mowing. Seed dispersal into the crop was only an issue 1 year after establishment of the field margin strips, particularly next to the unsown margin strip, and wind-borne seeds were dispersed over limited distances, mainly within the first $4 \mathrm{~m}$ of the adjacent crop. This suggests that margin management during the first years after establishment should be adjusted in order to prevent seed set.

\section{Acknowledgements}

This research was supported by the Federal Office for Scientific, Technical and Cultural Affaires (Prime Minister's Office, Brussels, Belgium), under the programme Global Change, Ecosystems and Biodiversity.

\section{References}

BÀrberi P \& Lo CASCIO B (2000) Long-term tillage and crop rotation on weed seedbank size and composition. Weed Research 41, 325-340.

Bokenstrand A, Lagerlöf J \& Torstensson PR (2004) Establishment of vegetation in broadened field boundaries in agricultural landscapes. Agriculture, Ecosystems and Environment 101, 21-29.

Bouman F, Boesewinkel D, Bregman R, Devente N \& Oostermeijer G (2000) Verspreiding van Zaden. KNNV, Utrecht, the Netherlands.

Campbell BD, Grime JP \& Mackey JML (1991) A trade-off between scale and precision in resource foraging. Oecologia 87, 532-538.

De Caumer B, Reheul D, D’hooghe K, Nijs I \& Milbau A (2005) Evolution of the vegetation of mown field margins over their first three years. Agriculture, Ecosystems and Environment 109, 87-96.

De Cauwer B, Reheul D, Nijs I \& Milbau A (2006) Dry matter yield and herbage quality of field margin vegetation as a function of vegetation development and management regime. Wageningen Journal of Life Sciences 54, 37-60.

De Vries DM \& De Boer TA (1959) Methods used in botanical grassland research in the Netherlands and their application. Herbage Abstracts 29, 1-7.

Feldman SR \& Lewis JP (1990) Output and dispersal of propagules of Carduus acanthoides L. Weed Research 30, 161-169.

Gomez KA \& Gomez AA (1984) Statistical Procedures for Agricultural Research, 2nd edn. John Wiley \& Sons, New York, USA. 
Howard CL, Mortimer AM, Gould P, Putwain PD, Cousens R \& Cussans GW (1991) The dispersal of weeds: seed movement in arable agriculture. In: Proceedings of the 1991 Brighton Crop Protection Conference - Weeds, Brighton, UK, 821-828. British Crop Protection Council, Farnham, UK.

Hume L \& ARChibold OW (1986) The influence of weedy habitat on the seed bank of an adjacent cultivated field. Canadian Journal of Botany 64, 1879-1883.

Hutchinson I, Colosi J \& Lewin RA (1984) The biology of Canadian weeds. 63. Sonchus asper (L.) Hill and S. oleraceus L. Canadian Journal of Plant Science 64, 731-744.

JoNES NE \& NAYLOR REL (1992) Significance of seedrain from set aside. In: Set-Aside (ed. J Clarke), 91-96. British Crop Protection Council, Surrey, UK.

KLEIJN D (1996) The use of nutrient resources from arable fields by plants in field boundaries. Journal of Applied Ecology 33, 1433-1440.

KLEIJN D (1997) Species richness and weed abundance in the vegetation of arable field boundaries. $\mathrm{PhD}$ thesis, Wageningen Agricultural University, Wageningen, the Netherlands.

Krause A \& Olson M (2000) The Basics of $S$ and S-Plus, 2nd edn. Springer-Verlag, New York, USA.

Leroux GD, Benoît DL \& Banville S (1996) Effect of crop rotations on weed control, Bidens cernua and Erigeron canadensis populations, and carrot yields in organic soils. Crop Protection 15, 171-178.

Marshall EJP (1989) Distribution patterns of plants associated with arable field edges. Journal of Applied Ecology 26, 247-257.

MARShall EJP (1990) Interference between sown grasses and the growth of rhizome of Elymus repens (couch grass). Agriculture, Ecosystems and Environment 33, 11-22.

Marshall EJP \& NowaKowski M (1992) Herbicide and cutting treatments for establishment and management of diverse field margin strips. Aspects of Applied Biology 29, 425-430.

Montegut J (1983) Pérennes et Vivaces Nuisibles en Agriculture. Département Jean Manuel de la S.E.C.N
Société d'Edition "Champignons et Nature", Aubervilliers, France.

NAYlor REL (2002) Weed Management Handbook. British Crop Protection Council, Blackwell Publishing Company, Oxford, UK.

Nevens F \& Reheul D (2002) Restoration of botanical diversity on heavy clay soil grassland in Flanders: management lessons from 9 years of trial. In: Proceedings of the 19th General Meeting of the European Grassland Federation 'Multi-function Grasslands' (eds JL Durand, C Huyghe \& G Lemaire), 820-821. EGF, La Rochelle, France.

Rew LJ, Froud-Williams RJ \& Boatman ND (1996) Dispersal of Bromus sterilis and Anthriscus sylvestris seed within arable field margins. Agriculture, Ecosystems and Environment 59, 107-114.

Smith H, Firbank LG \& Macdonald DW (1999) Uncropped edges of arable fields managed for biodiversity do not increase weed occurrence in adjacent crops. Biological Conservation 89, 107-111.

Tremmel DC \& Peterson KM (1983) Competitive subordination of a Piedmont old field successional dominant by an introduced species. American Journal of Botany 70, 1125 1132.

Van Der Meijden R (2005) Heukels' Flora van Nederland. Wolters-Noordhoff, Groningen, the Netherlands.

van der Meulen HAB, de Snoo GR \& Wossink GAA (1996) Farmers' perception of unsprayed crop edges in the Netherlands. Journal of Environmental Management 47, 241-255.

West TM, Marshall EJP \& Arnold GM (1997) Can sown field boundary strips reduce the ingress of aggressive field margin weeds? In: Proceedings of the 1997 Brighton Crop Protection Conference-Weeds, Brighton, UK, 985-990. British Crop Protection Council, Farnham, UK.

Westbury DB, Woodcock BA, Harris SJ, Brown VK \& Pоттs SG (2008) The effects of seed mix and managment on the abundance of desirable and pernicious unsown species in arable buffer strip communities. Weed Research 48, 113-123. 